\title{
High gain multiphase boost converter based-on capacitor clamping structure
}

\author{
Oday Saad Fares, Jasim Farhood Hussein
}

Department of Electrical Engineering, University of Technology, Baghdad, Iraq

\begin{tabular}{l} 
Article Info \\
\hline Article history: \\
Received Jun 14, 2021 \\
Revised Aug 31, 2021 \\
Accepted Sep 4, 2021 \\
\hline Keywords: \\
Capacitor clamping structure \\
DC-DC converter \\
High voltage gain \\
Multiphase boost converter
\end{tabular}

\begin{abstract}
In the last few years, the non-isolated dc converters involving high voltage gain with adequate performance are becoming quite popular in industrial applications. This is resulting in high voltage and current stress on the power device (switches and diodes), as well as a limited output voltage with a high duty cycle. This paper proposes a multi-phase non-isolated boost converter that uses capacitor clamping to increase output voltage while reducing stress across the power device. There are two stages in the proposed converter (first stage is three inductors and three switches and the second stage is clamper circuit of three capacitors and three diodes). The proposed converter is high voltage gain, with low voltage stress through switches transistors. To justify the theoretical analysis, the concept was validated through mathematical analysis and by simulation using MATLAB/SIMULINK. The results carried out the results permit the converter behavior and performance to be accurately.
\end{abstract}

This is an open access article under the CC BY-SA license.

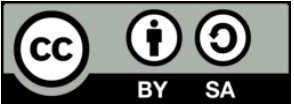

\section{Corresponding Author:}

Oday Saad Fares

Department of Electrical Engineering

University of Technology, Baghdad, Iraq

Email: eee.19.20@grad.uotchnology.edu.iq

\section{INTRODUCTION}

Due to its sustainable and endless source supply nature, renewable energy sources (photovoltaic, fuel cells, and uninterruptible power supply (UPS)) are developed continuously and swiftly replenished, and it is employed in remote places. The output voltage of these energy sources is still much lower than a direct current (DC) system requirement [1]-[3]. On the other side The large input current ripple, on the other hand, shortens the lifetime of photovoltaic (PV) and fuel cells [3]-[5]. High current ripple and unregulated low voltage are two major drawbacks of adopting renewable energy sources. As a result, in recent years, numerous approaches have been presented to achieve high voltage gain, reduced current ripple, component size reduction, and increased efficiency [1]-[25].

The traditional boost converter concept can be thought of as a basic key to suggesting a DC voltage boosting device. The typical boost converter, on the other hand, has some shortcomings, such as high input current ripple, voltage gain limitation, high current stress, and low efficiency. Another disadvantage of standard DC converters is that they have the biggest conduction losses due to the switching system, which is a major issue that affects the converter output power [6]-[8]. The used of high frequency pulsewidth modulation (PWM) topology is very important to increase voltage gain, reduce losses, ripple and component $\operatorname{siz}[9]-[11]$.

The multiphase switching inductors technique used as first stage is essentially a mix of three ordinary DC converters connected in a parallel layout. Because of the benefit of current redistribution among the phases, this configuration can reduce output voltage and input current ripple but the voltage conversion 
ratio still the same of conventional converter. Because the input current is shared according to multiphase in parallel, the multiphase switching approach has a faster transient response due to low switching losses. This benefit reduces their switching losses, increasing efficiency, and it also reduces current stress. In addition, due to the input distributed current, the size and component rating are lowered [12]-[15].

Using a clamper capacitor circuit in the second stage provides the following advantages:

a) A huge voltage spike was limited across switches by the passive clamp function [16].

b) Low voltage stress, high voltage gain and low input current ripple [17]-[20].

c) There is extra gain adding to main dc boost converter [21]-[25].

This paper offers a three-channel boost converter DC converter based on a capacitor clamping circuit. The capacitor clamping side achieves the high voltage gain. This design will provide low ripple at the input (current and voltage) and output (current and voltage) sides, as well as minimize switch element stress to the (Vout/3) lowerthan the output voltage.

\section{THREE PHASE BOOST CONVERTER BASED-ON CAPACITOR CLAMPING OPERATION IN (CCM) MODE}

Figure 1 is present the proposed converter. It is constituted by three channels inductors and capacitor clamping structure. The proposed converter consists of three shared inductors and switches that controlled by three PWM operation signals with 120-degree phase shift between them. The suggested converter has six modes of operation. The following is a discussion of the converter operating in continuous conduction mode during the steady state for one period.

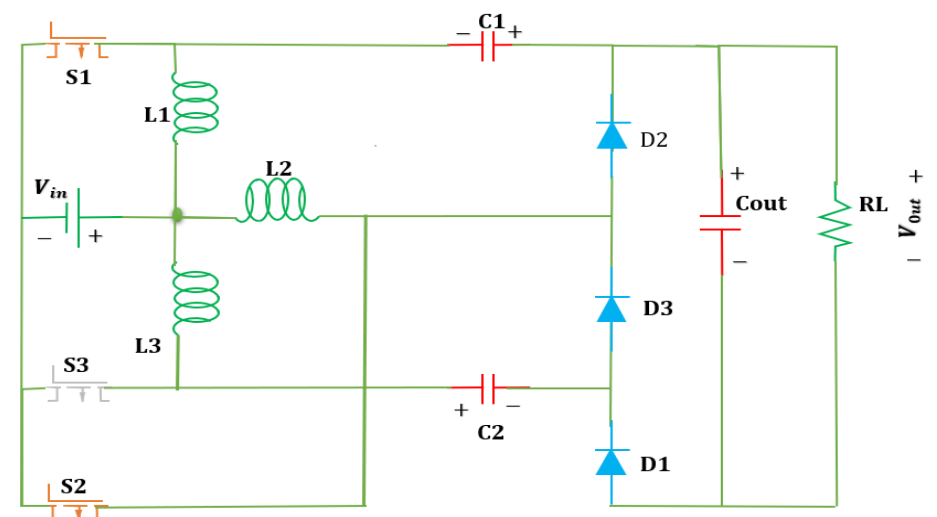

Figure 1. Proposed high gain multi-phase boost converter

a) Operational mode $\mathrm{I}$ : is shown in Figure 2. The three switches $\left(\mathrm{S}_{1}, \mathrm{~S}_{2}\right.$ and $\left.\mathrm{S}_{3}\right)$ are turned ON. Thus, the diodes $\mathrm{D}_{1}, \mathrm{D}_{2}$ and $\mathrm{D}_{3}$ tended to turn OFF (reverse bias state). This action causes storage energy in $\mathrm{L}_{1}, \mathrm{~L}_{2}, \mathrm{~L}_{3}$. While $\mathrm{C}_{\text {out }}$ are discharged its energy towards to the load side.

$$
\begin{aligned}
& V_{\text {in }}=L_{1} \frac{d_{L} 1}{d t}=L_{2} \frac{d i_{L 2}}{d t}=L_{3} \frac{d i_{L 3}}{d t} \\
& v_{\text {c out }}=v_{o}=R_{L} i_{o}
\end{aligned}
$$

b) Operational mode II: is shown in Figure 3. Where $S_{1}, S_{3}$ keep ON while $S_{2}$ is turned OFF. So, the diodes $D_{1}$ and $D_{3}$ are reverse bias state. Whereas $D_{2}$ is in $O N$ state (forward biased). In second mode the inductors $L_{1}$ and $L_{3}$ are stored energy with positive slope of $\frac{V_{\text {in }}}{L}$ where $L=L_{1}=L_{2}=L_{3}$. in the same time the supply energy $V_{\text {in }}$ and the stored energy in $L_{2}$ are transfer energy in series to $C_{1}$. Furthermore, $\mathrm{C}_{\text {out }}$ discharged its energy to $\mathrm{R}_{\mathrm{L}}$ in series.

$$
\begin{aligned}
& V_{\text {in }}=L_{1} \frac{d i_{L 1}}{d t}=L_{3} \frac{d i_{L 3}}{d t} \\
& V_{\text {in }}-L_{2} \frac{d i_{L 2}}{d t}-V_{c 1}=0 \\
& V_{\text {Cout }}=R_{L} i_{o}=V_{o}
\end{aligned}
$$




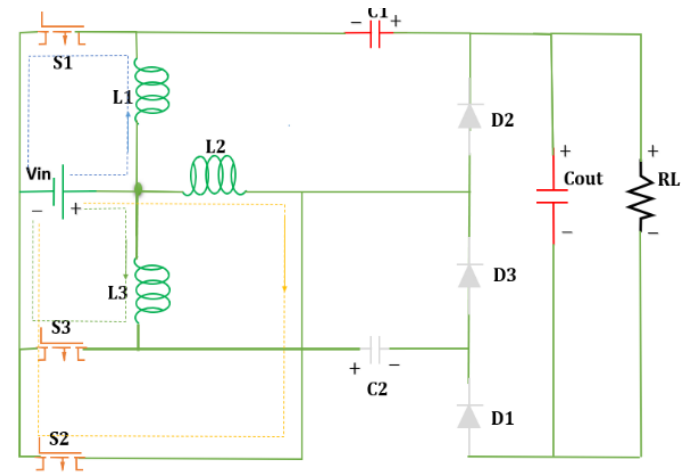

Figure 2. Mode 1, mode 3, and mode 5

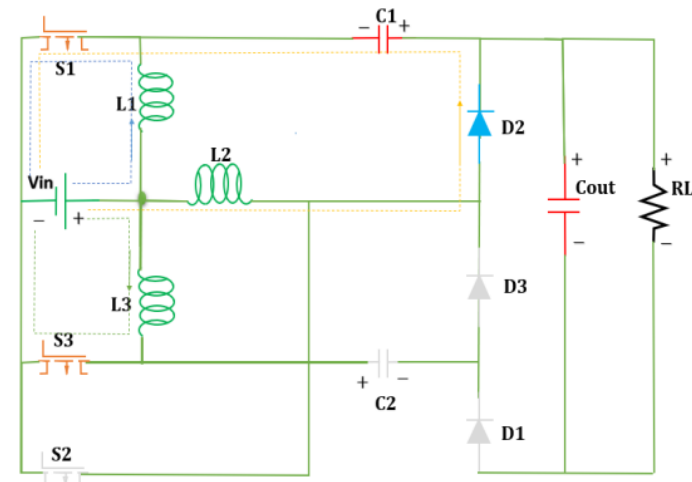

Figure 3. Mode 2

c) Operational mode III: $\left(\mathrm{S}_{1}, \mathrm{~S}_{2}\right.$ and $\left.\mathrm{S}_{3}\right)$ are $\mathrm{ON}$ state. So, is equivalent to mode I.

d) Operational mode IV: is shown in Figure 4. $S_{3}$ Is turned off while $S_{1}$ and $S_{2}$ keep turning-on. So, the diodes $\mathrm{D}_{1}$ and $\mathrm{D}_{2}$ are reverse bias state. Whereas $\mathrm{D}_{3}$ is in $\mathrm{ON}$ state (forward biased). In fourth mode the inductors $L_{1}$ and $L_{2}$ are stored energy with positive slope of $\frac{V_{\text {in }}}{L}$ where $L=L_{1}=L_{2}=L_{3}$. in the same time the supply energy $V_{i n}$ and the stored energy in $L_{3}$ are transfer energy in series to $C_{2}$. Furthermore, $\mathrm{C}_{\text {out }}$ discharged its energy to $\mathrm{R}_{\mathrm{L}}$ in series.

$$
\begin{aligned}
& V_{\text {in }}=L_{1} \frac{d i_{L 1}}{d t}=L_{2} \frac{d i_{L 2}}{d t} \\
& V_{\text {in }}-L_{3} \frac{d i_{L 3}}{d t}-V_{C 2}=0 \\
& V_{\text {Cout }}=R_{L} i_{o}=V_{o}
\end{aligned}
$$

e) Operational mode V: S1, S2 and S3 all are on. The operating principle is same as mode I.

f) Operational mode VI: As shown in Figure 5. The modes of operation waeforms shown in Figure 6. Where $S_{1}$ is turned off while $S_{2}$ and $S_{3}$ keep turning-on. So, the diodes $D_{2}$ and $D_{3}$ are reverse bias state. Whereas $D_{1}$ is in $O N$ state (forward biased) in sixth mode the inductors $L_{2}$ and $L_{3}$ are stored energy with positive slope of $\frac{V_{\text {in }}}{L}$ where $L=L_{1}=L_{2}=L_{3}$. in the same time the supply energy $V_{\text {in }}$ and the stored energy in $L_{1}$ are transfer energy in series with $V_{c 1}$ and $V_{C 2}$ transfer energy to $C_{\text {out }}$ and in the same time to $\mathrm{R}_{\mathrm{L}}$.

$$
\begin{aligned}
& V_{\text {in }}=L_{2} \frac{d i_{L 2}}{d t}=L_{3} \frac{d i_{L 3}}{d t} \\
& V_{\text {in }}-L_{1} \frac{d i_{L 1}}{d t}-V_{C 1}-V_{C 2}+V_{\text {Cout }}=0 \\
& V_{\text {Cout }}=R_{L} i_{o}=V_{o}
\end{aligned}
$$

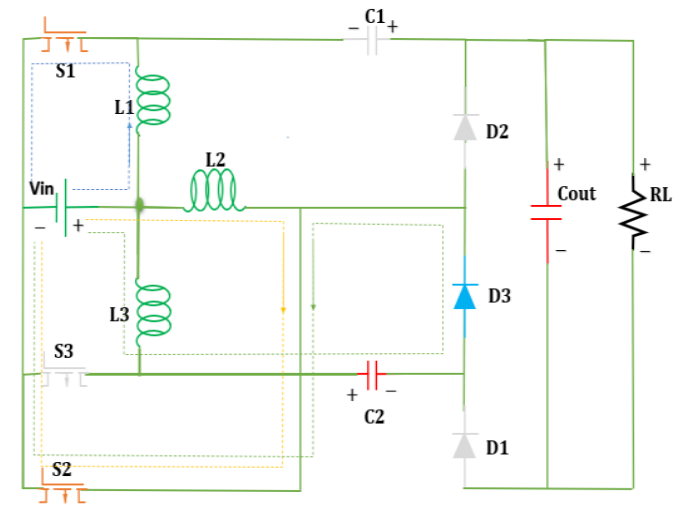

Figure 4. Mode 4

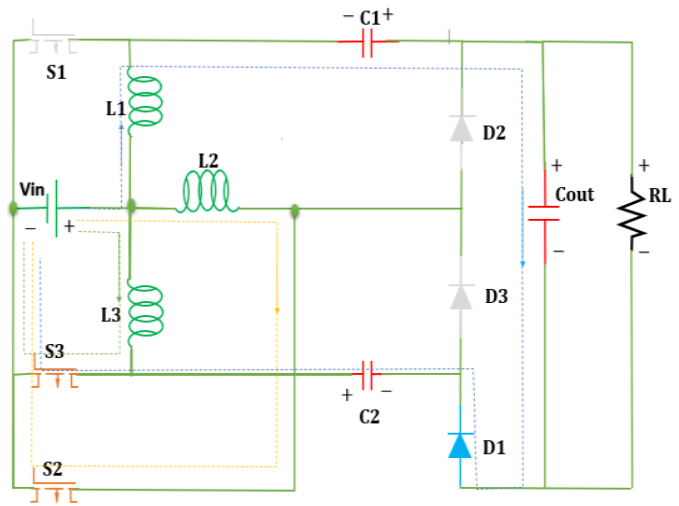

Figure 5. Mode 6 


\section{PROPOSED CONVERTER STEADY-STATE ANALYSIS}

\subsection{Voltage gain}

According to volt-second balance principle on $\mathrm{L}_{1}$, , can be obtained:

$$
\begin{aligned}
& \begin{aligned}
V_{\text {Lavg }}=V_{\text {in }} * t_{o n} & +\left(V_{\text {in }}-V_{c 1}\right) * t_{\text {off }}=0 \quad \text { where } t_{\text {on }}=D, t_{\text {off }} \\
& =(1-D)
\end{aligned} \\
& \begin{aligned}
V_{\text {Lavg }}=D V_{\text {in }}+(1-D)\left(V_{\text {in }}-V_{c 1}\right)=0 & \text { Where: D: on period, (1-D): off period. }
\end{aligned} \\
& V_{\text {in }}-V_{c 1}(1-D)=0 \text { so } V_{c 1}=\frac{V_{\text {in }}}{1-\mathrm{D}}
\end{aligned}
$$

Also, according to volt-second balance principle on inductor $L_{3}$ the capacitor 2 voltage as shown (13):

$$
\begin{aligned}
& V_{\text {Lavg }}=D V_{\text {in }}+(1-D)\left(V_{\text {in }}-V_{c 2}\right)=0 \\
& V_{\text {in }}-V_{c 2}(1-D)=0 \quad \text { so } \quad V_{c 2}=\frac{V_{\text {in }}}{1-\mathrm{D}}
\end{aligned}
$$

At last, according to volt-second balance principle on inductor $\mathrm{L}_{2}$ the output capacitor voltage as shown (14):

$$
\begin{aligned}
& V_{\text {Lavg }}=V_{\text {in }} * t_{\text {on }}+\left(V_{\text {in }}-\mathrm{V}_{\text {Cout }}+V_{c 1}+V_{c 2}\right) * t_{\text {off }}=0 \\
& V_{\text {Lavg }}=D V_{\text {in }}+(1-D)\left(V_{\text {in }}-\mathrm{V}_{\text {Cout }}+V_{c 1}+V_{c 2}\right)=0 \\
& \mathrm{~V}_{\text {Cout }}=V_{\text {in }} /(1-D)+\left(V_{c 1}+V_{c 2}\right)
\end{aligned}
$$$$
t_{\text {on }}=D \quad, t_{\text {off }}=(1-D)
$$

By sub $12 \& 13$ in 14 we get:

$$
\begin{aligned}
& V_{\mathrm{O}}=\mathrm{V}_{\text {Cout }}=\frac{V_{\text {in }}}{1-\mathrm{D}}+\left(V_{c 1}+V_{c 2}\right)=\frac{V_{\text {in }}}{1-\mathrm{D}}+\frac{V_{\text {in }}}{1-\mathrm{D}}+\frac{V_{\text {in }}}{1-\mathrm{D}} \\
& V_{\mathrm{O}}=3 \frac{V_{\text {in }}}{1-\mathrm{D}}
\end{aligned}
$$

\subsection{Input current ripple}

The input current for the proposed converter will distributed among three inductors $\mathrm{L}_{1}, \mathrm{~L}_{2}, \mathrm{~L}_{3}$ with phase shift of 120 degree in switches operation between switches. Therefore, the operatetion frequency of the input current will be three times than operation frequency of switching Figure 6.

$$
\Delta \mathrm{I}_{\mathrm{in}}=\frac{3 \mathrm{~V}_{\mathrm{in}} \mathrm{D}}{\mathrm{LF}_{s w}}
$$

\subsection{Output voltage ripple}

The output voltage ripple can be reduced by the proposed converter because of the output frequency three times than the input frequency as shown in Figure 6:

$$
\mathrm{V}_{\text {ripple }}=\frac{\Delta \mathrm{V}_{\mathrm{o}}}{\mathrm{V}_{\mathrm{o}}}=\frac{\mathrm{D}}{3 \mathrm{~F}_{s w} \mathrm{CR}_{\mathrm{L}}}
$$

\subsection{Semiconductor voltage stress}

\subsubsection{Voltage stress across the switches}

From mode 2, mode 4 and mode 6 the voltage stress across switches $S_{3}, S_{2}$ and $S_{1}$ as shown in Figure 6.

$$
\mathrm{V}_{\mathrm{S} 2 \text { stress }}=\mathrm{V}_{\mathrm{S} 1 \text { stress }}=\mathrm{V}_{\mathrm{S} 3 \text { stress }}=\frac{\mathrm{V}_{\mathrm{in}}}{1-\mathrm{D}}=\frac{V_{o}}{3}
$$

\subsubsection{Voltage stress across the diodes}

The voltage stress across diode when diode be in reverse biasing, and it explained below:

- Voltage stress across $D_{1}$ pass in two stages: Stage 1 in mode 2 and Stage 2 in the mode 4.

$$
\begin{aligned}
& V_{D 1 \text { stress }}=V_{\text {Cout }}-\left(V_{C 1}+V_{C 2}\right)=\frac{V_{\text {in }}}{1-D}=\frac{V_{\text {out }}}{3} \\
& V_{\text {D1 stress }}=V_{\text {Cout }}-V_{C 1}=V_{\text {D1 stress }}=\frac{2 V_{\text {in }}}{1-D}=\frac{2 V_{\text {out }}}{3}
\end{aligned}
$$

- Voltage stress across $D_{2}$ pass in two stages: Stage 1 in the mode 4 and Stage 2 in the mode 6. 


$$
\begin{aligned}
& V_{D 2 \text { stress }}=V_{C 1}=\frac{V_{\text {in }}}{1-D}=\frac{V_{\text {out }}}{3} \\
& V_{D 2 \text { stress }}=V_{\text {Cout }}-V_{C 2}=\frac{2 V_{\text {in }}}{1-D}=\frac{2 V_{\text {out }}}{3}
\end{aligned}
$$

- Voltage stress across $D_{3}$ pass in two stages: Stage 1 in the mode 2 and Stage 2 in the mode 6 .

$$
\begin{aligned}
& V_{D 3 \text { stress }}=V_{C 2}+V_{C 1}=\frac{2 V_{\text {in }}}{1-D}=\frac{2 V_{\text {out }}}{3} \\
& V_{D 3 \text { stress }}=V_{C 2}=\frac{V_{\text {in }}}{1-D}=\frac{V_{\text {out }}}{3}
\end{aligned}
$$

The voltage stress across diodes with respect to modes of operation are shown in Figure 6.

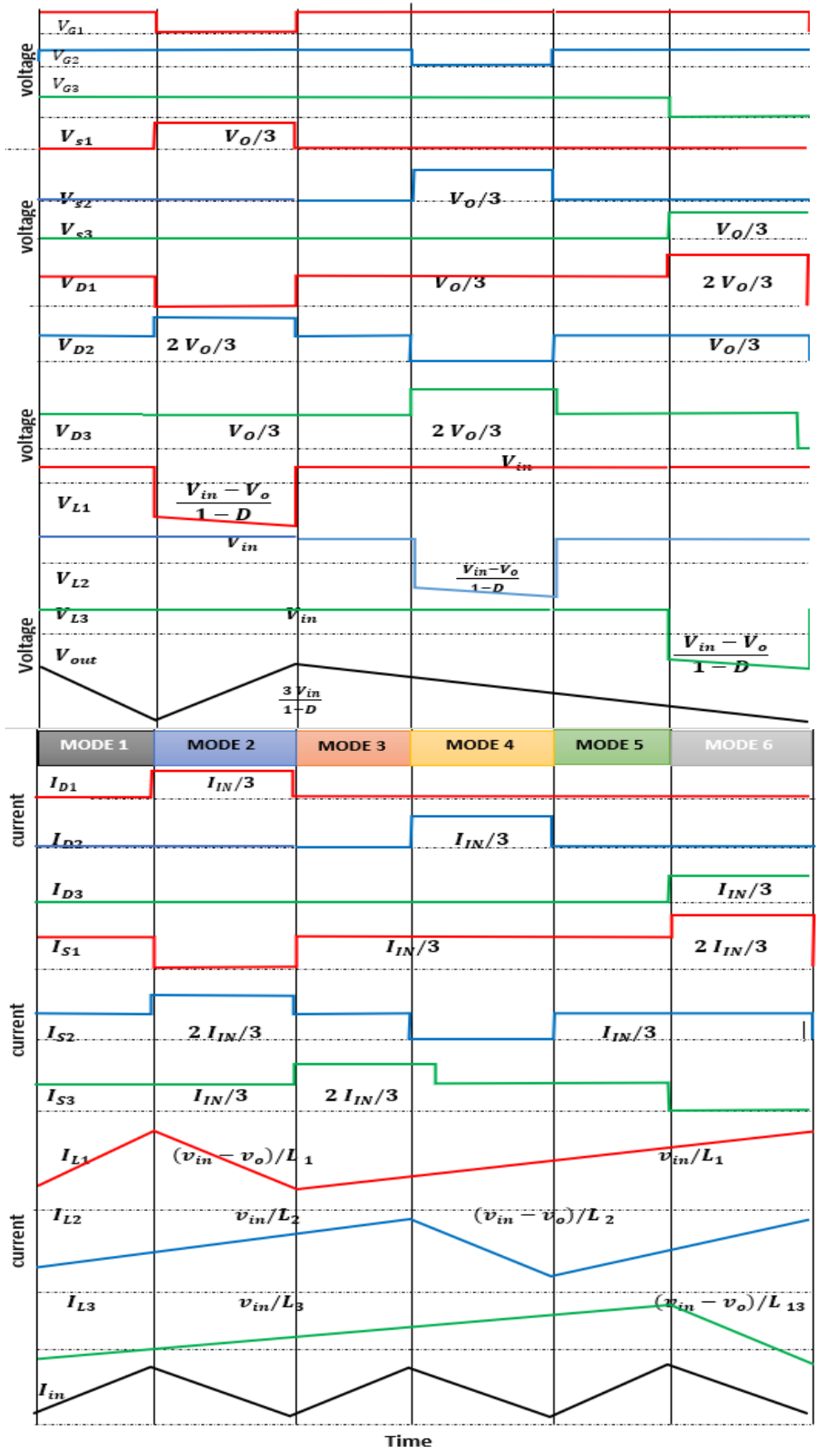

Figure 6. Key waveform for proposed converter 


\section{SIMULATION AND RESULTS}

The use of MATLAB R2018B to simulate the proposed converter and converter parameter listed in Table 1. The three control signals with phase shift 120 degree shown in Figure 7. Output voltage is $480 \mathrm{~V}$ as shown in Figure 8. The three inductors voltages waveform are shown in Figure 9 voltage stress across diodes is $160 \mathrm{~V}$ as shown in Figure 10. The maximum voltage stress across switches is $320 \mathrm{~V}$ as shown in Figure 11.
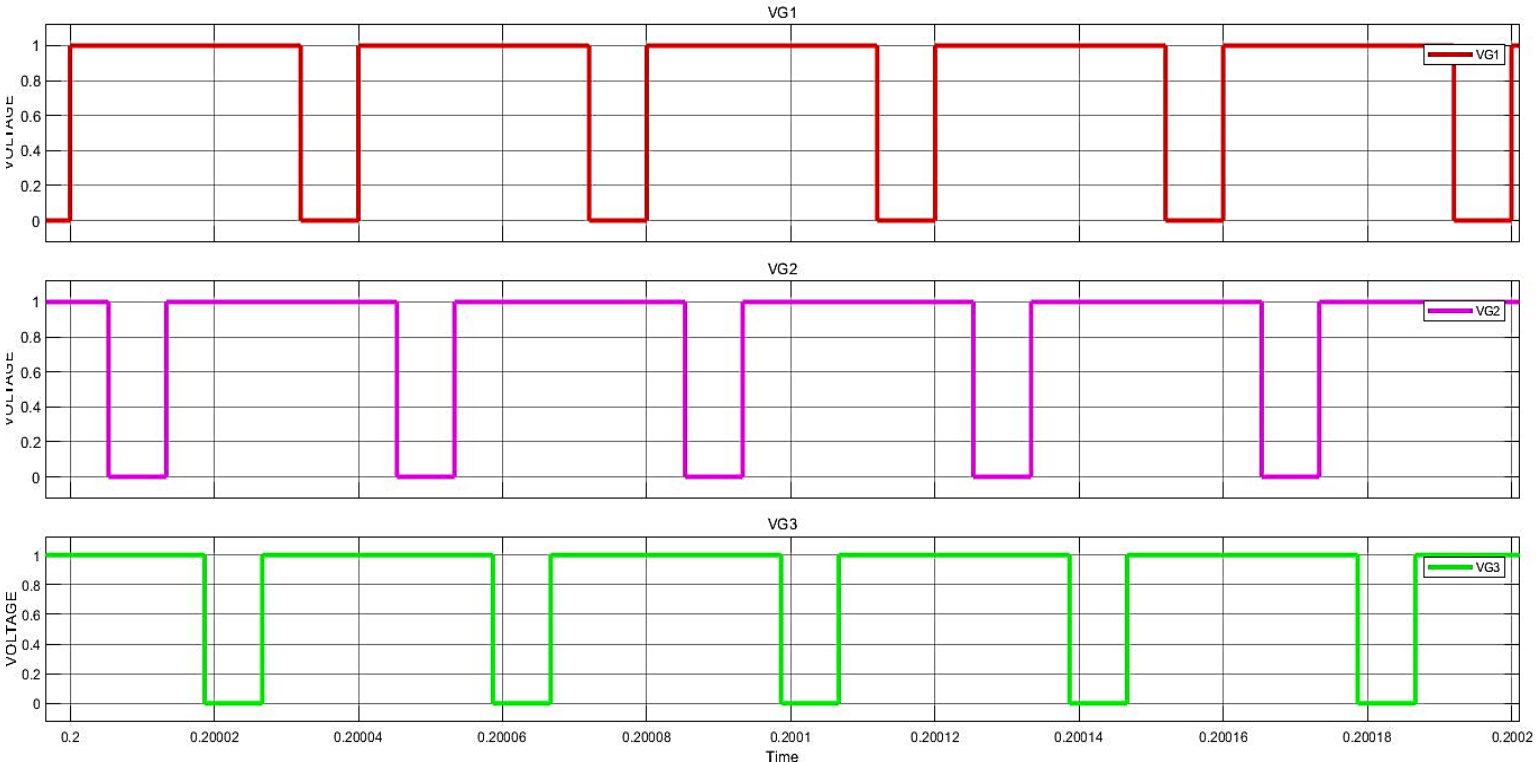

Figure 7. Power switches voltage control waveform

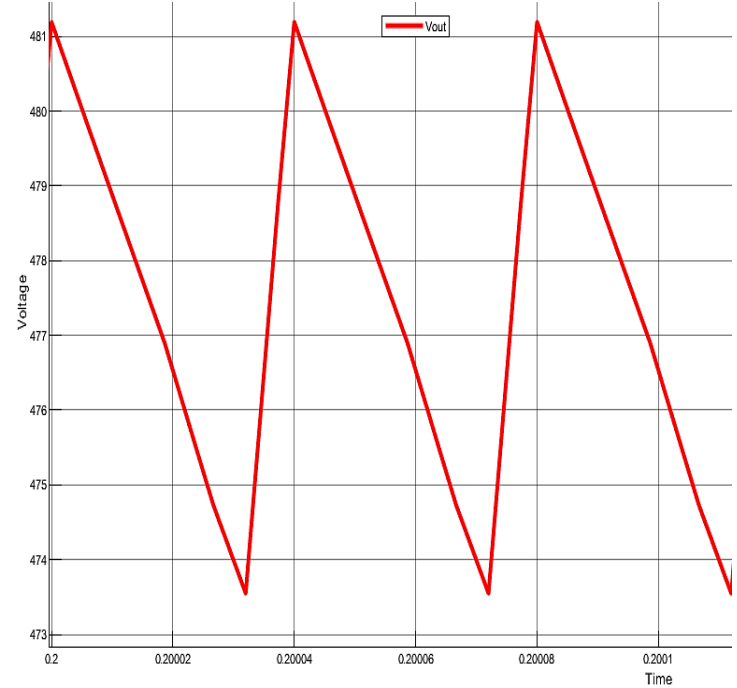

Figure 8.Output voltage waveform
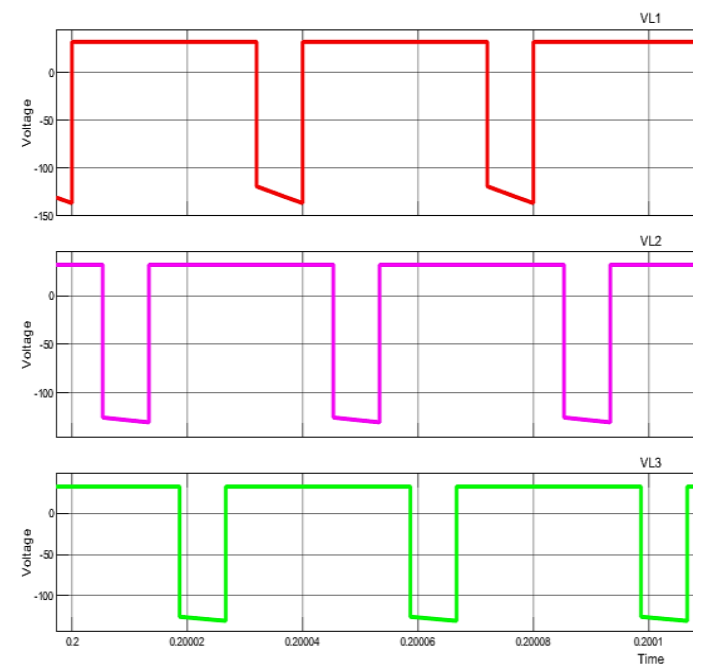

Figure 9. Inductors voltage waveform

Table 1. Parameter of the proposed converter

\begin{tabular}{cc}
\hline Parameter & Value \\
\hline$L_{1}, L_{2}, L_{3}$ & $700 \mu \mathrm{H}$ \\
$C_{1}, C_{2}, C_{3}$ & $20 \mu \mathrm{F}$ \\
Load Resistance $R_{L}$ & $230 \Omega$ \\
Switching Frequency $-\mathrm{f}_{\mathrm{sw}}$ & $25 \mathrm{kHz}$ \\
Input Voltage & $32 \mathrm{~V}$ \\
Output Voltage & $480 \mathrm{~V}$ \\
Duty Cycle & $80 \%$ \\
\hline
\end{tabular}



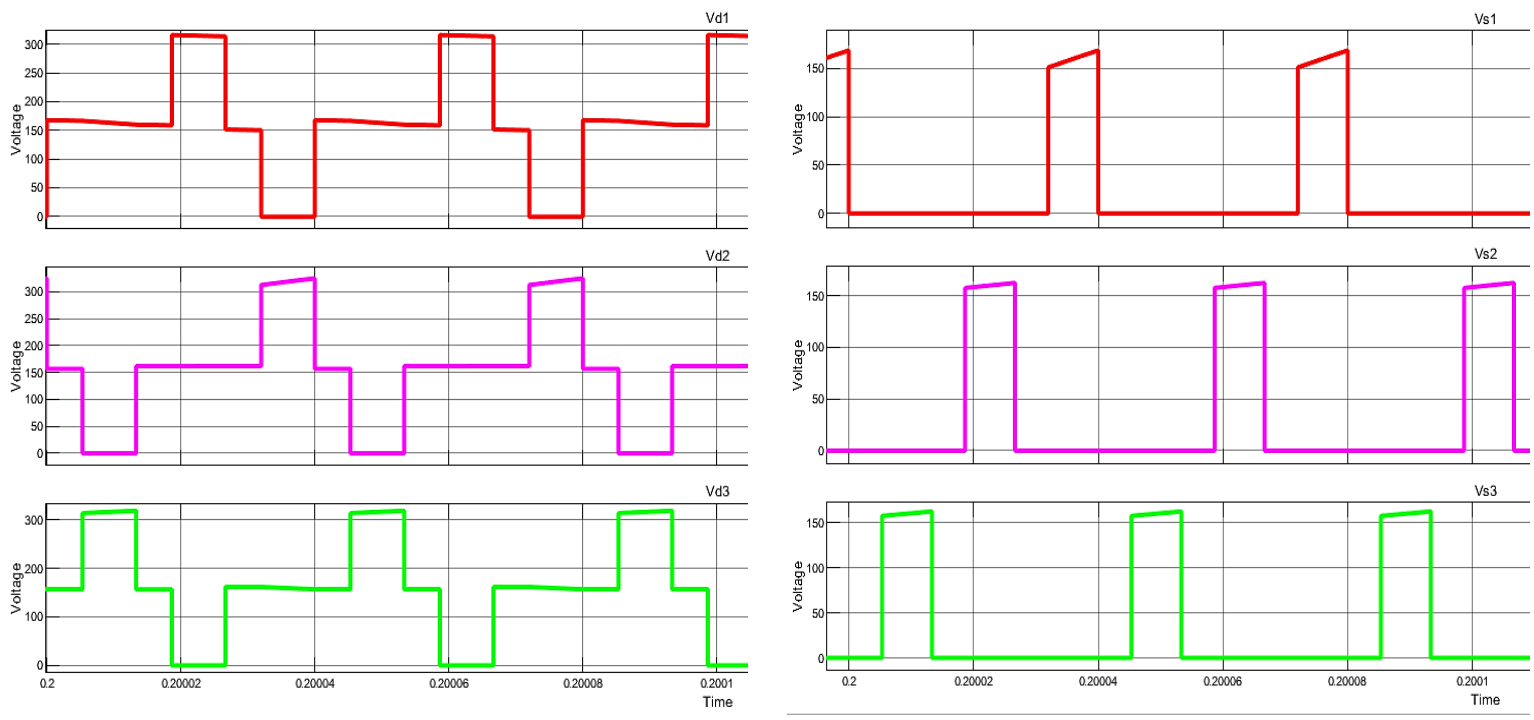

Figure 10. Voltage stress across switches waveform

Figure 11. Voltage stress across diodes waveform

\section{CONCLUSION}

This paper presented a non-isolated DC-DC converter consist of two construction (three shared inductor and clamper capacitor circuit). This converter fed by single input source. The converter provides a high transformation ratio, lower voltage stress across power device (switches and diodes). The proposed converter suitable for power application where using renewable energy (P. V, Fuel cell and UPS) source. Because the input current of this source will be continuous and has lowest ripple. In this paper illustrated the analysis of the proposed converter and its design and checked it with MATLAB Simulation. The efficiency of proposed converter is $93 \%$. Because of lower voltage stress across power device the total cost of converter will reduced.

\section{REFERENCES}

[1] R. L. Yngdoh Mairang and B. Goswami, "Design of DC Microgrid Based on Photovoltaic Power Supply System," ADBU Journal of Electrical and Electronics Engineering (AJEEE), vol. 2, no. 2, pp. 54-63, September 2018.

[2] H. Li, W. Wang, Y. Zeng, Y. Zhao, and Y. Jiang, "A 3L Capacitor Clamping DC-DC Converter with Low Current Ripple and High Voltage Gain," IEEE Energy Conversion Congress and Exposition, ECCE, pp. 4366-4371, 2019, doi: 10.1109/ECCE.2019.8912843.

[3] K. Kommuri and V. R. Kolluru, "Implementation of modular MPPT algorithm for energy harvesting embedded and IoT applications," International Journal of Electrical and Computer Engineering (IJECE), vol. 11, no. 5, pp. 3660-3670, October 2021, doi: 10.11591/ijece.v11i5.pp3660-3670.

[4] N. Tewari and V. T. Sreedevi, "A novel single switch dc-dc converter with high voltage gain capability for solar PV based power generation systems," Solar Energy, vol. 171, pp. 466-477, 1 September 2018, doi: 10.1016/j.solener.2018.06.081.

[5] A. M. Al-Modaffer, A. A. Chlaihawi, and H. A. Wahhab, "Non-isolated multiple input multilevel output DC-DC converter for hybrid power system," Indonesian Journal of Electrical Engineering and Computer Science (IJEECS), vol. 19, no. 2, August 2020, pp. 635-643, doi: 10.11591/ijeecs.v19.i2.pp635-643.

[6] M. L. Alghaythi, R. M. O. Connell, N. E. Islam, and J. M. Guerrero, "A Multiphase-Interleaved High Step-up DCDC Boost Converter with Voltage Multiplier and Reduced Voltage Stress on Semiconductors for Renewable Energy Systems," IEEE Power \& Energy Society Innovative Smart Grid Technologies Conference (ISGT), 07 May 2020, doi: 10.1109/ISGT45199.2020.9087696.

[7] A. F. Gani, A. A. Bakar, A. Ponniran, M. Hussainar, and M. A. N. Amran, "Design and development of PWM switching for 5-level multiphase interleaved DC/DC boost converter," Indonesian Journal of Electrical Engineering and Computer Science (IJEECS), vol. 17, no. 1, pp. 131-140, January 2020, doi: 10.11591/ijeecs.v17.i1.pp131-140.

[8] R. Seyezhai, R. Anitha, S. Mahalakshmi, and M. Bhavani, "High Gain Interleaved Boost Converter for Fuel Cell Applications," Buletin Teknik Elektro dan Informatika (Bulletin of Electrical Engineering and Informatics), vol. 2, no. 4, pp. 265-271, December 2013, doi: 10.11591/eei.v2i4.192.

[9] A. M. Dobi and M. R. Sahid, "Overview of soft-switching DC-DC Converters," International Journal of power and drive System (IJPEDS), vol. 9, no. 4, pp. 2006-2018, December 2018, doi: 10.11591/ijpeds.v9.i4.pp2006-2018.

[10] C. R. Balamurugan, S. P. Natrajan, R. Bensraj, and B. Shanthi, "A Review on Modulation Strategies of Multi Level Inverter," Indonesian Journal of Electrical Engineering and Computer Science (IJEECS), vol. 3, no. 3, pp. 681-705, September 2016, doi: 10.11591/ijeecs.v3.i3.pp681-705. 
[11] D. Chowdhury, M. S. Miah, M. F. Hossain, and U. Sarker, "Implementation of a grid-tied emergency back-up power supply for medium and low power application," International Journal of Electrical and computer Engineering (IJECE), vol. 10, no. 6, pp. 6233-6243, December 2020, doi: 10.11591/ijece.v10i6.pp6233-3243.

[12] S. Saravanan and N. R. Babu, "A modified high step-up non-isolated DC-DC converter for PV application," Journal of Applied Research and Technology, vol. 15, no. 3, pp. 242-249, June 2017, doi: 10.1016/j.jart.2016.12.008.

[13] M. Kavitha and V. Sivachidambaranathan, "New improved two-phase interleaved converter with clamp circuit and diode capacitor cell," Microprocessors and Microsystems, vol. 75, pp. 1-10, June 2020, doi: 10.1016/j.micpro.2020.103035.

[14] M. Bhaskar, G. Ganesan, and Narayanan K3, "Interleaved Hybrid Boost Converter with Switched Capacitor Technique," IEEE PES Innovative Smart Grid Technologies Asia, pp. 3890-3895, 2019, doi: 10.1109/ISGTAsia.2019.8881462.

[15] A. Alzahrani, P. Shamsi, and M. Ferdosi, "A Novel Interleaved Non-Isolated High-gain DC-DC Boost Converter with Greinacher Voltage Multiplier Cells," $6^{\text {th }}$ International conference on Renewable energy research and application, San Diego, CA, USA, 2017, pp. 22-227, doi: 10.1109/ICRERA.2017.8191270.

[16] M. A. Salvador, T. B. Lazzarin, and R. F. Coelho, "High-Step Up DC-DC Converter With Active SwitchedInductor and Passive Switched - Capacitor Networks," IEEE Transactions on Industrial Electronics, vol. 65, no. 7, pp. 5644-5654, 2018, doi: 10.1109/TIE.2017.2782239.

[17] B. S. Revathi, P. Mahalingam, and F. Gonzalez-Longatt, "Interleaved high gain DC-DC converter for integrating solar PV source to DC bus," Solar Energy, vol. 188, pp. 924-934, August 2019, doi: 10.1016/j.solener.2019.06.072.

[18] A. Mittle, R. K. Singh, and S. Chandra J. A., "A New Interleaved High Step-up DC-DC Converter," IEEE Students Conference on Engineering and Systems (SCES), May 2019, pp. 29-31, doi: 10.1109/SCES46477.2019.8977225.

[19] J. S. Prasad, Y. P. Obulesh, and Ch. Sai Babu, "Three-Phase Three-Level Soft Switching Dc-Dc Converter for Industrial applications," International Journal of power electronics and drive System (IJPEDS), vol. 8, no. 2, pp. 785-794, June 2017, doi: 10.11591/ijpeds.v8.i2.pp785-794.

[20] M. E. Azizkandi, F. Sedaghati, and H. Shayeghi, "A New Boost DC-DC Converter Based on a Coupled Inductor and Voltage Multiplier Cells," International Journal of Electronics Control and Optimization, vol. 2, no. 4, pp. 265-278, Oct 2019, doi: 10.22111/IECO.2019.28215.1127.

[21] F. M. Shahir, E. Babaei, and M. Farsadi, "Voltage-Lift Technique Based Non-Isolated Boost DC-DC Converter: Analysis and Design," IEEE Transactions on Power Electronics, pp. 1-10, doi: 10.1109/TPEL.2017.2740843.

[22] P. Getzial Anbu Mani, and A. K. Parvathy, "High gain boost converter with modified voltage multiplier for standalone PV system," Indonesian Journal of Electrical Engineering and Computer Science (IJEECS), vol. 14, no. 1, pp. 185-192, April 2019, doi: 10.11591/ijeecs.v14.i1.pp185-192.

[23] G. Jegadeeswari, V. Vanisree, and S. Janarthanan, "Performance Analysis of DC-DC converters with voltage-lift Circuits," International Journal of Management, Technology and Engineering, vol. 8, no. 7, pp. 139-152, July 2018.

[24] M. Premkumar, U. Subramaniam, H. H. Alhelou, and P. Siano, "Design and Development of Non-Isolated Modified SEPIC DC-DC Converter Topology for High-Step-Up Applications: Investigation and Hardware Implementation," Energies, pp. 1-27, 2020, doi: 10.3390/en13153960.

[25] B. S. Revathia, P. Mahalingama, and F. Gonzalez-Longattb, "Interleaved high gain DC-DC converter for integrating solar PV source to DC bus," Solar Energy, vol. 188, pp. 924-934, August 2019, doi: 10.1016/j.solener.2019.06.072.

\section{BIOGRAPHIES OF AUTHORS}

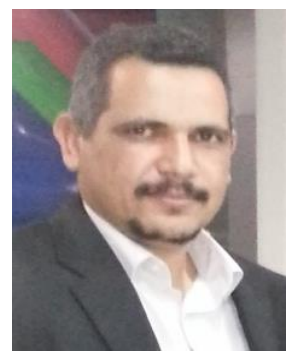

Oday Saad Fares was born in Baghdad, Iraq in 1978. He received the BSc in Electrical Engineering from university of technology Iraq in 2000 in 2019. He is currently working toward the M. Sc degree in Electrical Engineering at university of technology, Iraq. His research interest are the area of DC/DC converters, controller design and renewable energy.

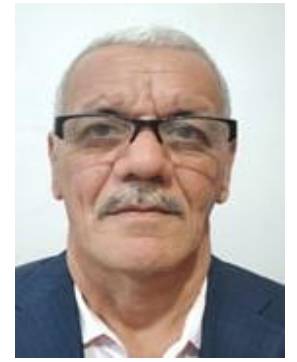

Dr. Jasim Farhood Hussein lecturer in the University of Technology Department of Electrical Engineering Iraq-Baghdad. He received the BSc. and M. Sc in Electrical Engineering from university of technology Iraq-Baghdad in 1989 and 2003 respectively. And he received the $\mathrm{PhD}$ in Electrical Engineering in 2013 from De Montfort University UK. His area interest includes of power electronics field and renewable energy. 